\title{
THE PROBLEM OF LONGITUDE AT SEA IN THE 18TH CENTURY IN SPAIN
}

\author{
Antonio Lafuente and Manuel A. Sellés \\ Instituto "Arnau de Vilanova" (CSIC). Faculty de Medecine, Ciudad \\ Universitaria. Madrid -3 . Spain
}

Few scientific subjects have generated so much literature or so many expectations as the reckoning of longitude at sea. Since the 16 th century numerous authors, including several charlatans and opportunists, took on the study of a topic which, apart from presenting a challenge to the scientific community, could also offer substantial economic benefits to the person who managed to find the solution. A long inventory of essays could be listed which described methods which were only viable on paper, but absolutely impracticable on board ship. It would not be until the eighteenth century that this research led to even minimally precise processes, with strong support from the different European monarchs. But even when found, these processes would not be easy to apply. Few countries had a scientific or technical infrastructure capable of guaranteeing the assimilation of methods which involved advanced. mathematical knowledge and/or handmade precision mechanisms. Obviously it was possible to find an Elite with the education to follow the advances being made in astronomy and instrumentmaking techniques, but this was in no way sufficient. We are not confronted here with a merely theoretical problem, but a practical one, whose solution could have important consequences for trade and the domination of the Atlantic. Rather than being an academic exercise, the measurement of geographical longitude affected the security of sailing, and both merchant seamen and naval officers were deeply involved in it. Thus, appropriate institutions were required by the methods proposed from the middle of the century, to ensure the teaching of scientific and professional skills to sailors. However, although important, the mere importation of knowledge from European centres of scientific activity did not guarantee selfsufficiency in matters which affected maps or existing navigational courses.

This paper describes the efforts made in 18th century Spain to acquire and adopt technology and knowledge on how to work out a ship's position.

\section{THE SPANISH NAVY AND SCIENCE IN THE 18TH CENTURY}

The process of introducing and institutionalizing modern science in Spain presents extraordinarily interesting and varied facets. In general, the 17 th century had been an age of isolation and decadence with respect to the novelties produced abroad. After a period of dialectical confrontation between different cultural sectors in Spain at the end of the 17 th century, in which a group of 'innovators' took up battle to conquer an intellectual territory where science could be introduced, a new stage began, in which new advances were absorbed in a more or less peaceful manner. The Treaty of Utrecht confirmed English domination of the Atlantic and woke Spain from its long imperial dream with the arrival of the new Bourbon dynasty. Amongst the policy priorities of Felipe V's ministers was the re-establishment of manufacturing and the revitalization of economic activity in the colonies. None of this could be carried out without the back-up of a Fleet capable of protecting the trade monopoly of Cadiz. 
The navy was required to play an outstanding role as motor and main destiny of the considerable investment which had to be made. Its reconstruction did not only demand administrative reforms, but also the training of officers who could become cartographers of the seas and coasts, sail an exact course with a boat, set up royal arsenals, manufacture cannons and artillery parts and oversee the building of ships and frigates. All this made up a programme to update science and its techniques in order to reduce Spanish dependence on other countries, for which there were neither institutions nor groups in spain capable of heading such a process. Unlike other countries, in Spain it was the military bodies which had almost exclusive dealings with the promotion, protection and financing of scientific activity for several decades. The transition from a crude imperialism to the rationalization of navigation methods, naval construction or manufacturing was begun from its institutions, which were often accused of being a privileged place for the confrontation of the nobility of the gown against the nobility of the sword. The absence of strong private commercial enterprise impeded the development of a technology similar to that abroad, such that the reality being studied here was extremely bureaucratic, hierarchic, centralized and militaristic. Below, we shall see what effect this had on the problem with which we are dealing.

\section{THE INTRODUCTION AND DISSEMINATION OF METHODS FOR MEASURING LONGITUDE}

The development of efficient methods for measuring longitude at sea began in the middle of the 18th century. Two methods competed together in this, neither exempt of difficulties. The first was mechanical, consisting in comparing the time at the local meridian with the time obtained at the meridian of embarcation which was conserved in a chronometer carried in the boat. The second was purely astronomical, and enabled the longitude to be worked out by deducing the time at the reference meridian from the angular distance observed between the moon and a predetermined star and the use of some ephemerides referring to the meridian of origin (1). Although the chronometric method was somewhat simpler, the techniques needed to construct precision isochronic mechanisms which would be insensitive - in practical terms - to variations in temperature and the ship's movements, etc. were extraordinarily complex. However the lunar distance method required deeper mathematical knowledge and a skilled observation technique with reflecting instruments of the sort designed by Hadley. But, apart from its lower cost (for marine chronometers were scarce and in great demand), it also had the advantage of being a technique which was within the grasp of trained observers. Since the sky was always the same for all observers, they could work out the tabulated distances by using the time of a reference meridian as their key (2). Nonetheless, both methods were the result of applying an extremely complex technology which few European countries could claim to possess. The first required the existence of workshops and highly skilled techicians, whilst the second demanded the establishment of observational training centres and a sort of astronomical calculating method, both of which were slow and costly to institutionalize. We will try to describe the efforts made in Spain for the acquisition of the technology already mentioned as well as its naturalization within the scope of Spanish technological self-sufficiency.

The first marine chronometer to give even minimally satisfactory results was built by John Harrison around the first third of the century. Fifty years later, following a series of rapid technical advances in workshops with a high level of labour division and specialization, the first chronometers came onto the market as instruments which were both rare and costly. At the same time, the excellent tables for the Moon drawn up by Tobias Mayer in Göttingen and sent to the Board of Longitude enabled the Astronomer Royal, Nevil Maskelyne to start with the publication of the Nautical Almanae (1767), thus making the method available to navigators, even if only to an enlightened sort of navigator, very unlike the often crude, experienced officers of the Merchant Navy. 
Following the scientific espionage mission which Jorge Juan carried out in London after taking part in the Spanish-French geodetic expedition for measuring of one degree from the equator in Quito, Spain became familiar with the First advances of Harrison (3). In 1750, Juan informed the Marquis de la Ensenada, Naval Secretary, that he had seen the chronometer and explained the great problems he might encounter in buying it (4). But later stop-overs of French expeditions in Cadiz, headed by Cassini (1768), Fleurieu (1768-69) and Verdun, Borda y Pingre (1771-72), who had set out to test the clocks of Pierre le Roy and Ferdinand Berthoud, enabled the personnel of the observatory and the Academia de Guardias Marinas to obtain firsthand information on chronometers and other methods.

More should be said about the distance method which, based on the British almanac, began to be applied from 1772 onwards. In this year the naval officers, Juan de Lángara and Jose de Mazarredo, sailing in the frigate 'Venus' destined for Manila, calculated the position of the ship by determining the longitude from the Moon and its distance from the Sun, using the Connaissance des Temps. The nautical almanacs for 1772 and 1773 were acquired during a stopover of a British ship, and we are told that from then on these were in constant use on voyages made by this method (5). Once their reliability had been proven, the necessary steps were taken to organize a two-month course in the Cadiz Academia as quickly as possible, to train the naval officers and navigators in such techniques.

Three years later, when new Marine Guards Academies were established in the three maritime departments, Mazarredo incorporated the processes for determining longitude by both chronometer and distance into the timetable of the Cartagena Academia, a practice which was later extended to the other two as well. The regular sending of the Nauticat Atmanac from England to the Cadiz Observatory, the nerve centre of Spanish astronomy and seafaring, shows that interest in the method did not diminish.

In 1783, the war with England having come to an end, a period of reflection on the stucture of the Navy began, which led to new efforts at renovation. The teaching schedules in the Escuelas de Pilotos and the Academias de Guardias Maminas were reformed; a "Course for Further Studies" was started up, to train those 'scientific officers' to be able to carry out any sort of scientific or technical comission; the observatory was given its definitive structure, being assigned a fixed quota of qualified officers to take on the mission of a systematic programme for the making, centralization and accumulation of observations; at the same time, a tight programme of hydrographic expeditions was drawn up, to map the peninsular and colonial costs. Here one should underline the important scientific-technical dimension which was given from the central government itself as an urgent reaction to the difficulties faced by Spanish squadrons during the war. The renewal of the role played by officers with mathematical skills reinforced a trend which had existed since the foundation of a Cadet Academy in 1717. The subsequent replacement of the archetypal fighting officers, crude on the sea and gentlemen at court, could not avoid heightening the tensions between the sword and the pen within a body with little inclination towards academic discussion (6). Although tense, this situation was of decisive benefit to eighteenth century Spanish science. In the absence of other institutions, the Navy took on almost exclusive responsibility for the training of astronomers and navigators (7). Amongst the problems they had to cope with, few were seen as more important than the measuring of longitude. Some of the most outstanding efforts of the Bourbon's' scientific policy were thus concentrated on its solution.

The Compendio de Navegacion (1757), published by Jorge Juan, constituted a magnificent exponent of the power of the modernization of knowledge. From the $80^{\prime} \mathrm{s}$ onwards, the most recent advances demanded to be acted upon; the new Tratado de Navegacion (1787) by Jose de Mendoza y Ríos incorporated a detailed study of existing methods for measuring 1 ongitude. 
However, for the moment, only the Navy could provide the skills necessary to form an Elite. From 1792 these subjects would also be explained to navigators trained in private Nautical Schools, which began to proliferate after the liberalization of trade with America (8), which had been a Cadiz monopoly up until then. Both Mendoza's treaty and the lessons given by Jose de Mazarredo in Cartagena gave preference to the direct trigonometry process, without recourse to tables or methods for simplifying the process of 'clearing' the distance (9). Such practice was only accessible to some naval officers, whose mathematical training had been strengthened in the academic curricuza, for there was no doubt that the numerous and complex series of calculations and operation required by this method were beyond the grasp of merchant seamen. It therefore seemed urgent to make more general use of the techniques proposed by Maskelyne, Borda, Dunthone and Lyons, which Mendoza y Rios explained, albeit from too theoretical a point of view. Soon, more elementary works appeared in Spanish and the necessity arose to publish nautical and astronomical tables which would be more accessible than the French and British ones, calculated from the first Spanish meridian, that of the Cadiz observatory.

Once again the Navy, and especially its Observatory, were confronted with the task of drawing up a Spanish nautical almanac. A precedent existed from 1785 in the form of the tables included in the Estado General de Marina, whose efficiency was open to discussion, due to the fact that it did not appear early enough. In 1791 some tables were also printed in Murcia 'under orders from above', which disseminated Dunthorne's method as it appeared in the second edition of the Tables Requisite (1781) and which was based on the distances published in the Nautical Atmanac or in the Connaissance des Temps. The first volume of the annual series, Almanaque Nautico, which came out in 1792, was financed by the astronomy officers of the Observatory, who, due to other jobs they had to concentrate on, limited themselves to reproducing the distance tables from the Nautical Almanac, as had been done in the Connaissance from 1774 to 1778 , but transferring them to the Cadiz Observatory. The technology was being imported, but it still had to be adapted to Spanish needs. This was of vital importance given that, in the words of Mazarredo, "it would be a slur of which we could never rid ourselves if we used foreign workers when we had people at home who could do the job" (10). The huge work entailed in the calculation of some nautical and astronomical ephemerides, albeit not totally calculated for the first Spanish meridian, soon made the necessity obvious of establishing a Calculating office which, as an annex of the Observatory, would be specifically dedicated to the drawing up of the Atmanaque. By then it was obvious that if a staff of calculators wished to have sufficient continuity, it would have to be formed from civilians who would not be affected by the changes of military personnel due to expeditions, campaigns or promotion. But this was not easy to achieve in spain. Once again, it was necessary to turn to the individuals of the Artillery Corps, who would be prepared to abandon their military posts in exchange for a good salary. There would be four calculators who would be integrated into the office, which did not function without certain tensions, since there was no possibility of promotion within it to jobs reserved for military graduates from the centre. Despite this, the continuity of the ephemerides was not interrupted, nor was the path taken towards nationalization. By 1810 lunar distances were calculated directly for the Isla de Leon meridian, the place to which the Observatory had moved from Cadiz.

Furthermore, the Almanaque Natitico, which tried to extend its usefulness to astronomy and serve as a vehicle for the diffusion of scientific reports and essays, also included some work on the calculation of distance. Thus, the volumes for 1795, 1796 and 1801 included work by the officers, F. Lopez Royo and Dionisio Acalá Galiano and explicitly mentioned Bowditch's method. Alongside this publication, other papers also taught more about the new processes of nautical astronomy. Keeping strictly to the subject of longitude, we can mention the Memoria sobre algunos metodos de caleular la Longitud por las Distancias Lunares (Madrid 1795) by José de Mendoza y Ríos, Memoria sobre las observaciones de Latitud y Longitud en la mar 
(Madrid 1796) by Francisco Lopez Royo, whose appearance entailed the total and complete presentation of the different methods in existence. Shortly after, they were followed by the works of Gabriel Clscar within the field of graphical methods for "clearing" lunar distances.

Up until now, we have dealt with the lunar distance method and its gradual penetration into Spain. Let us now turn to the subject of longitudinal time-measurement. This process was less widely used since, although it was easy for a sailor to get hold of a good sextant, it was unlikely that he would own a chronometer which had to be bought in London at a comparatively high price and which needed complex maintenance. In this terrain too, the Spanish Navy tried to carry out a decisive policy of technological assimilation.

\section{THE INTRODUCTION OF THE MARINE CHRONOMETER}

As aiready stated, advances of longitudinal time-measurement were followed closely by the Spanish Admiralty. In 1765, Jorge Juan, in a report to the Minister following the publication of Harrison's work on the tests carried out with his clocks, gave a detailed history of the question and suggested sending spies to England "to lean with Harrison himself, whilst trying to keep him happy; for herein lies the benefit, and in the case of a wheel breaking, there should be someone who knows how to rebuild it." (11). We have not been able to find out whether the matter was ever taken any further with Harrison, but, whatever the case, no progress was made until, in 1774, chronometers were bought from the French clockmaker, Berthoud - numbers 7, 9, 10 and 12 - and then, two years later, his chronometers numbers 13, 14, 15 and 16 were also purchased. As can be seen, the Spanish government almost monopolized the production of this French artisan's first time-keepers which shows the interest which existed in the subject. Such purchases were not only made in France. There is also proof of the acquisition of chronometers nos. 3, 5 and 6 from Arnold. These costly instruments soon had an important assignment. From 1783, the hydrographic programme already mentioned was begun with the expedition to draw up maps and sailing books on the Spanish coasts (1783-87), encharged to the then director of the Academia $y$ observatorio de Guardias, Marinas vicente Tofiño. Berthoud's chronometers nos. 10 and 13 were used on this mission. These same clocks would later accompany Malaspina in his expedition around the world.

This whole programme was backed up on the one hand by staff trained in the "Course for Further Studies" and, on the other, by the Naval Observatory, as centre of nautical work and deposit for the select instruments which had been bought in great numbers from London. Amongst these, we should mention the existence, in 1804, of more than two dozen chronometers in varying states of conservation. But evidently this was not enough. Although chronometers had been purchased right from the start, for some reason or other no care had been taken to establish an adequate infrastructure for their upkeep. Timekeepers needed to be cleaned at least once every two years, and this oversight threatened to ruin the entire investment. When Berthoud sold his clocks, he offered to train a pensioner, but did not receive any reply. Nothing was done in this respect as long as the chronometers worked; but ten years after having bought them, they were all in need of attention and nos. 9 and 10 needed to be repaired. Attempts to get Tomás Lozano, a Cadiz clockmaker, to take this on, did not produce satisfactory results. Thus, in 1788 four were sent to Berthoud - to be followed shortly by all the others - and he took the opportunity to renew his offer, but it did not arouse the right sort of response from the administrative authorities. The timekeepers arrived in Paris in a terrible condition due to the journey (12); the problem of their maintenance and repair could not be put off any longer. The ministry received yet another offer from the French craftsman, this time directly through the Spanish Consul in Paris. Jose de Mazarredo strongly recommended that it be accepted, and when the ministry put him in charge of the matter, he went around all the Madrid clockmakers and asked for information from other Spanish cities, in search of someone suitable 
to be sent to Paris. He finally decided on Cayetano Sánchez, a young student at the Escuela de Relojeria, a clockmakers' school which the Charost brothers had set up in Madrid. Berthoud's offer, for which he received ample compensation, not only extended to the cleaning and mending of the chronometers, but also to teaching Sánchez how to build marine chronometers like his.

From then on, no effort was spared in order to give the apprentice the best possible training. In 1791, having successfully completed his studies with Berthoud he went around other Parisian workshops and established contacts and perfected the technique. Once his education in France had come to an end, he was sent to London, where he enrolled in Emery's workshop under the condition that the Spaniard would not establish himself later on in Paris. But marine chronometers did not only present mechanical problems. The hard stones used in their construction required a refined technique. Mazarredo chose Antonio Molina from amongst the students of the Escuela de Relojería to be sent to London in order to learn it.

In 1793 Sánchez returned to Spain and formalized his contract with the Navy. In this, it was stipulated that he should move to the Isla de Leon - to which place the Observatory was about to be transferred - and set up a clockmaking workshop in a building which would be designated for this purpose. He would have to maintain all the observatory's timekeepers and pendulums, as well as repair all those sent to him from other maritime departments. He was also obliged to repair Naval officers' privately-owned chronometers for the cost of materials alone, and, obviously, to build whatever he was commissioned to make. He would have an official helper in the workshop, another student from the Escuela in Madrid. He was free to establish himself as a private clockmaker and chronometrist beyond the obligations of the contract.

This sort of contract, which laid down a modest wage and the chance to work privately, was aimed at avoiding the danger of inactivity for lack of economic stimuli, at the same time as to naturalize the technique by offering a public service. The obligation to build marine timekeepers on commission in theory satisfied the Navy's needs. The final condition, that he should repair officers' private chronometers, shows that they must have purchased several, since those kept in the Oservatory were only given out in special cases.

However, after this auspicious start, a curse seemed to fall upon the recently established workshop. Molina died in Paris at the beginning of 1798, and the yellow fever epidemic which swept through Cadiz and its region in 1800 killed off Sánchez and all his helpers. The workshop was left deserted, the investment lost and hopes of teaching some dozens of clockmakers so that they could ensure self-sufficiency in this important field were totally frustrated. Once again it would be necessary to start buying chronometers from abroad. It had been hoped that this effort, in the words of Mazarredo "would place the Country on a par with France and England in this branch and relieve us of the enormous outlay necessary for purchasing timekeepers, which have become objects of prime necessity, no-one with the wherewithal to pay for one wanting to be without one" (13). The eulogy Mazarredo gave for Sánchez folowing his death shows that, although he could not be compared with craftsmen such as Berthoud or Arnold, he fully met the Navy's necessities. "Sánchez," he said, "may have been far from being an Arnold in terms of invention and advances. But in the state of the art of clockmaking up until now, in carrying out what Arnold had already instigated, he was this man's equal" (14).

The workshop empty and its jobs available, some Spanish clockmakers wanted to take it over. All applications had to be rejected in view of the lack of training they had in such a sophisticated technique. A rapid decision was taken to return along the route of sending two new apprentices to Paris with Louis Berthoud, who stood out as a worthy successor to his uncle. 
Augustín Albino and Blas Muñoz were chosen for this four-year training on the basis of a contract similar to that of their predecessor. When they returned to the workshop they again had to resolve the problem of maintenance for all the Navy's chronometers, which were in no better condition than they had been before. Insufficiencies began to show up, and criticisms were made at this new stage. Spain lacked the adequate industrial infrastructure which had made the rapid development of English chronometry possible. A cumulation of problems prevented Spanish precision clockmaking from ever going beyond the narrow margin of the Naval workshop and the maintenance of the Navy's chronometers: 1ack of market, the endemic shortage of raw materials - stones, springs and other materials had to be imported from abroad - and the absence of specialized craftsmen who were capable of setting up the construction of chronometers on a production line basis so that they could be competitive, meant that the workshop was born without a future in this second stage of its existence. Furthermore, the Navy, in its bleak situation after the wars with England and France at the end of the century, no longer required new chronometers. The profound economic crisis which Spain went through in the first decades of the 19 th century made it unable to face the costs of such expensive establishments. All Spanish scientific activity was on a downard path to total decadence. Nonetheless, what was fundamental had to be saved, and the Naval observatory was one of the most solid institutions inherited by the Liberals. But, in keeping with the times, a clear demarcation had to be made between nautical functions and astronomical ones. J. Ortiz Canelas, Observatory Director (1804-1825), proposed, amongst other measures, the restructuring of the clockmaking workshop as a private concern and the cutting of its links with an institution which wanted it to be exclusively astronomical. There was a lot of resistance from within the Navy, since some of the most important officials could not understand what purpose would be served by a centre which was not primarily nautical. In 1818 Ortiz Canelas' proposal was approved. The Spanish navy no longer had the strength it used to have in earlier decades and was incapable of keeping up a demand which could have made possible the maintenance or consolidation of a technology in which so much had been invested.

\section{CONCLUSION}

We believe that the process described provides an excellent example of the difficulties encountered by a country which, like Spain, was on the periphery of the European centres of scientific activity, in achieving the incorporation of some extraordinarily sophisticated techniques. The mere sending of apprentices abroad, contribution of funding and the existence of several scientists was not sufficient. All this was done, and there was no lack of the essential scientific institutions to back up the establishment of a stable professional community, but it was not enough. The State exerted a sustained pressure through the Navy, but a more wide-reaching social demand was missing. When trade with America was belatedly liberalized, the renovation of nautical and navigational studies was slow in starting up. Parallel to this, the necessary accumulation of capital was not made to facilitate the formation of a domestic market and the strengthening of manufacturing. Within a framework of very centralized and bureaucratic production structures, projects for scientific and technical renovation went ahead at an uneven pace, without the necessary continuity and along 1 ines which often had little to do with the country's realities. Individuals were trained to set up a workshop for making timekeepers, but demand was not strong enough for individual labour to generate production systems with specialized labour division within it, or for naturalization of the techniques to be made possible in the only manner feasible - continued renovation similar to that carried out in English or French workshops. The entire effort hung upon one thread. If the armed struggle with England, which was always in the air and for which the Spanish Navy was prepared, turned out negatively, all the infrastructure created around it could be blown down with one breath. The workshop for the production of chronometers had been artificially implanted, and the death of one of its members or the scourge of an epidemic 
frustrated all the efforts made for it. And although it met with better luck, the rapid introduction but difficult general assimilation of the other technique for determining longitude can be interpreted in a similar manner. Its inclusion in timetables at academies was delayed until 1792, and even if the efforts which led to the independence of the Spanish Almanaque Nautico were concluded in 1810, Spanish traders had already lost the American market some decades earlier. Lunar distances never progressed from the stage of being a method to whose development some Spanish scientists contributed as a theoretical, academic problem and throughout the century, spain did not know how to take advantage of it and make the efforts to put it to good use which other European countries applied.

\section{NOTES}

1. Information on these subjects, in R.T. Gould, The Marine Chronometer. Its Histomj and Development, London, 1923; Alan C. Davies, "The Life and Death of a Scientific Instrument: the Marine Chronometer, 1770-1920", Annals of Science, 35 (1978), 509-525; E.G. Forbes, The Birth of Navigational Science, Maritime Monographs and Reports, No. 10, National Maritime Museum, Greenwich, 1974; E.G.R. Taylor, Navigation in the Days of Coptain Cook, Maritime Monographs and Reports, No. 18, National Maritime Museum, Greenwich, 1974; D.H. Sadler, Man is not Lost. A record of two hundred years of astronomical navigation with The Nautical Almanac, 1767-196?, London, 1968.

2. In short, the time was read in the celestial sphere, using the moon in rather the same way as the hand of a watch, and translating its position to the time of the meridian of origin by means of the Ephemerides.

3. A. Lafuente and J.L. Peset, "Polftica cientffica y espionaje industrial en los viajes de Jorge Juan y Antonio de Ulloa (1748-1751)" Melanges de la Casa de Velazquez (Paris), $17(1981), 233-262$.

4. "I have seen the Machine," he said, "And I would have liked it to be possible to buy it so that we did not lack it from its beginnings". Jorge Juan to the Marquis de la Ensenada; London, 23rd February 1750. Museo Naval (Madrid), Ms.2413, Document 10.

5. Almanaque Nautico y Efemerides astronomicas (1792), p.v.

6. See A. Lafuente and M.A. Selles, "La milicia academizada: el conflicto entre la pluma y la espada durante la primera mitad del siglo XVIII", III Coloquio de Historia de la Educacion: Educacion e Ilustracion en España, Barcelona, 1984.

7. M.A. Sellés and A. Lafuente, "La formación de los pilotos en la España del siglo XVIII", in press; A. Lafuente, "La enseñanza de las ciencias durante la primera mitad del siglo XVIII", Estudios dedicados a Juan Peset Aleixandre, 3 vols., Valencia, 1982, 2 , pages $477-493$.

8. This liberalization process proceeded gradually from 1765 , culminating in the Free Trade Ruling of 1778. The Schools, promoted by the Consulates of the different ports with licences for America, began to appear from this date on. Amongst them, we should mention the Schools at Barcelona (1796), Arenys de Mar (1779), Malaga (1787) and La Coruna (1790).

9. This term refers to the reduction of the apparent distance to the real distance, 'clearing' it of the effects of refraction and parallax.

10. Jose de Mazarredo to the Naval Minister, Antonio Valdes, Madrid, 27th September 1791. Reporting on a proposal made by Jose de Mendoza y Ríos from Paris to start up the A manaque by employing French calculators. Library of E1 Instituto y Observatorio de Marina, (San Fernando, Cadiz), recently discovered manuscripts, pending classification.

11. Jorge Juan to the Naval Minister, Julián de Arriaga, Madrid, 12th Apri1 1765 . Quoted by C. Fernández Duro, "Cronometría", Disquisiciones Nâuticas, vol. 4, Madrid, 1879, p. 138 .

12. "Je les ai aussitot fait dèballer," said F. Berthoud, "Et j'ai vu avec autant de surprise que de chagrin que ces Machines sont arrivees dans le plus mauvais état". F. Berthoud to Jose de Espinosa Te11o; Paris, 9th June 1788. Museo Naval, Ms. 1565, Doc. 4.

13. José de Mazarredo to Antonio Corne1; Paris, 21st November 1800. Archivo General de Marina (E1 Viso del Marqués, Guadalajara), Leg. Observatorio. Asuntos particulares, $1797-1804$.

14. Ibid. 